\title{
Universiteit
}

Leiden

The Netherlands

\section{Climate change, violent conflict and local institutions in Kenya's drylands}

Adano, W.R.; Dietz, A.J.; Witsenburg, K.; Zaal, A.F.M.

\section{Citation}

Adano, W. R., Dietz, A. J., Witsenburg, K., \& Zaal, A. F. M. (2012). Climate change, violent conflict and local institutions in Kenya's drylands. Journal Of Peace Research, 49(1), 65-80. Retrieved from https://hdl.handle.net/1887/18493

Version: $\quad$ Not Applicable (or Unknown)

License: $\quad$ Leiden University Non-exclusive license

Downloaded from: https://hdl.handle.net/1887/18493

Note: To cite this publication please use the final published version (if applicable). 


\section{Journal of Peace Research}

http://jpr.sagepub.com/

\section{Climate change, violent conflict and local institutions in Kenya's drylands}

Wario R Adano, Ton Dietz, Karen Witsenburg and Fred Zaal

Journal of Peace Research 2012 49: 65

DOI: $10.1177 / 0022343311427344$

The online version of this article can be found at:

http://jpr.sagepub.com/content/49/1/65

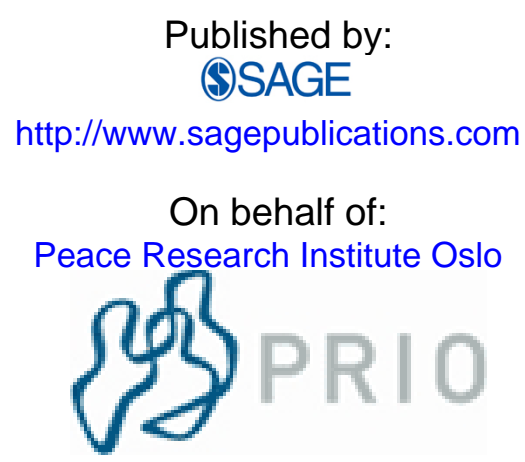

Journal of Peace Research Replication Data

Additional services and information for Journal of Peace Research can be found at:

Email Alerts: $\mathrm{http}: / / \mathrm{jpr}$.sagepub.com/cgi/alerts

Subscriptions: http://jpr.sagepub.com/subscriptions

Reprints: http://www.sagepub.com/journalsReprints.nav

Permissions: http://www.sagepub.com/journalsPermissions.nav

>> Version of Record - Jan 31, 2012

What is This? 


\title{
Climate change, violent conflict and local institutions in Kenya's drylands
}

\author{
Wario R Adano \\ Max Planck Institute for Social Anthropology, Halle/Saale
}

Ton Dietz

African Studies Centre, Leiden

Karen Witsenburg

Both ENDS, Amsterdam \& Max Planck Institute for Social Anthropology, Halle/Saale

Fred Zaal

Royal Tropical Institute, Amsterdam

\begin{abstract}
Many regions that are endowed with scarce natural resources such as arable land and water, and which are remote from a central government, suffer from violence and ethnic strife. A number of studies have looked at the convergence of economic, political and ecological marginality in several African countries. However, there is limited empirical study on the role of violence in pastoral livelihoods across ecological and geographical locations. Yet, case studies focusing on livelihood and poverty issues could inform us about violent behaviour as collective action or as individual decisions, and to what extent such decisions are informed or explained by specific climatic conditions. Several case studies point out that violence is indeed an enacted behaviour, rooted in culture and an accepted form of interaction. This article critically discusses the relevance of geographical and climatic parameters in explaining the connection between poverty and violent conflicts in Kenya's pastoral areas. These issues are considered vis-à-vis the role institutional arrangements play in preventing violent conflict over natural resources from occurring or getting out of hand. The article uses long-term historical data, archival information and a number of fieldwork sources. The results indicate that the context of violence does not deny its agency in explanation of conflicts, but the institutional set-up may ultimately explain the occurrence of the resource curse.
\end{abstract}

\section{Keywords}

climate change, Kenya's drylands, local institutions, resource curse, resource scarcity, violent conflict

\section{Natural resource wealth, climate change and violent conflict}

This article looks at the possible links between environmental factors and collective behaviour. A direct causal link between society and the physical environment has long been dismissed as physical determinism (Cole, 1996), because there is no direct relationship between, for instance, economic performance and the natural resource base. Yet, others have alluded to a strong relationship between the supply of environmental resources and the occurrence of violent conflict (Homer-Dixon, 1999; Kahl, 2006). These divergent views about the connection between scarcity and conflict indicate the complex issues that have continued to draw out academic debate (Collier \& Hoeffler, 1998;

Corresponding author:

roba@eth.mpg.de 
de Soysa, 2002; Gleditsch, 1998; Homer-Dixon, 1999). Until now the mainstream thinking has been that scarcity of resources creates war and conflict (Kaplan, 1994; Homer-Dixon, 1999). However, resource scarcity might actually foster cooperation over resources rather than trigger conflict (see also Buhaug, Gleditsch $\&$ Theisen, 2008).

The Human Development Report 2007/2008 most prominently emphasized the consequences of climate change for human security (UNDP, 2007; IPCC, 2007) rather than just being an environmental issue. Africa is termed a continent with climate-dependent economic sectors at risk of violent ethnic conflict. Climatechange predictions for Africa suggest increasing scarce water resources associated with a high risk of violent conflict, and declining and failing agricultural yields in the Horn of Africa (Carius, 2009; OECD, 2008). Burke et al. (2009) found correlations between changes in temperature or high levels of variability in rainfall and the likelihood of violent conflict events in Africa. The question arises, therefore, whether Kenya, which is experiencing the drying up of lakes and rivers, dwindling water supplies, and serious food shortages, is facing a typical situation with conflict induced by environmental scarcity.

The changes in rainfall patterns and frequent droughts make the survivability of pastoralists in the arid environments particularly difficult (Boko et al., 2007). Cyclical droughts are increasing in frequency, with the drought cycle, on average, increasing from one in eight years to one every three years. Interannual and interseasonal variations in rainfall patterns determine pastoral mobility and the use of fall-back grazing areas, intercommunity relations and altered land tenure arrangements, and conflict to the detrimental use of the rangelands. The availability of common-pool resources across border areas leads to periodic conflicts in the drylands. Conflicts between pastoral communities in the arid borderlands of northern Kenya, southern Sudan and southern Ethiopia are said to be over access to pasture and water, livestock raiding and the heavy presence of small arms (Leff, 2009). The fighting between pastoralists and farmers in the Oromia and Ogaden regions of Ethiopia, and interclan fighting in Somalia all seem to indicate the links between the human impacts of climate change and the threats of violent conflicts (Human Impact Report, 2009).

Lobell et al. (2008) predict a 54\% increase in armed conflicts in sub-Saharan Africa by 2030 compared to the 1980 to 2000 period, if future wars are as deadly as recent wars. Burke et al. (2009) report strong historical linkages between civil war and temperature increase in Africa. These claims were later refuted by Buhaug (2010a,b), who shows that, using a more accurate method of investigation and by making use of a more complete armed conflict dataset, there is no causal relationship.

The risk of increased conflict trends in Africa are likely a result of many complex reasons, including inadequate governance, rampant corruption, heavy dependence on natural resources and ongoing cycles of violent conflict (Halden, 2007; Olsson, Eklundh \& Ardö, 2005). Buhaug, Gleditsch \& Theisen (2008) give an overview of multiple factors that may play a role in the evolution of climate change-related violence, yet emphasize that there is no up-to-date empirical statistical evidence of violence directly related to climate change and environmental scarcities. Natural resources usually seem like the obvious cause, but conflict may be triggered by the absence of good institutions and external interference. A study of Northern Kenya found that it is not drought, but the coming of the rains that is associated with greater conflict casualties (Witsenburg \& Adano, 2009). Pastoralists do not fight during a time of scarcity but during periods of plenty, and the disruption of livelihoods remains a major concern for security policies. In combination with economic, social and political uncertainties, climate change might increase the risks of conflict and instability, especially under conditions of poor governance.

The actual impacts of climate change remain controversial and speculative. According to Ostrom (1990) and Young (2011) natural resources, including common-pool resources such as forests, grazing pastures and fisheries, are at times better managed collectively. Ostrom (1990) explains that self-governing institutions under common property rights are able to regulate many resources for collective benefits, as people learn to cooperate when presented with a resource problem. In this regard, institutions become a decisive variable in shaping human-environment interaction, and in preventing competition over resources turning into a violent conflict (Ostrom, 2007; Young, 2011). We do not argue that resource scarcity or abundance bring about (violent) conflict by themselves, but aim to provide evidence of how and under what conditions natural resources contribute to cooperation or violent conflict. This article shows the outcome of an enquiry into the relationship between climate change, natural resources availability and marginality (ecological and political) and social interactions between ethnic groups. The article seeks to answer the question whether we can develop an approach that combines the physical environment and human agency 
mediated by social institutions in explaining why natural resources and violence are not always directly related. The examples come from Kenya, where in the last couple of years violent incidents attracted much attention.

This work links up with the current debate on the demographic and social consequences of climate change in particular by linking ethnic violence and natural resource availability. Violent killing and raiding take place in a social context that may be motivated by considerations other than climate. In the first case of northern Kenya, cooperation increases in the dry season as natural resources become scarcer, and violence increases during the wet season. Against this background, the issues of governance and cooperation turn out to be relevant for our inquiry into the role of resource scarcity in low-productivity arid areas. In the second case of southern Kenya, the Loita forest as a contested resource also turned out not to be a resource curse $^{1}$ because of the management regime and an ingenious use of old and new institutions that prevented the loss of the forest to a private 'developer'. The benefits from the communally used forest remained well distributed among the local inhabitants.

The article draws a parallel between the conventional notions of resource scarcity inducing violent conflict, on the one hand, and the resource curse as it relates to abundant endowments of natural resources, on the other. We use these concepts to investigate the importance of the local institutions in access to and use of environmental resources. Natural resource regulations and governance arrangements play an important role in handling potential conflicts over scarce water resources in the drylands and in community-shared forest resources, even when climate change seems evident. For instance, while Africa generally is expected to get hotter and drier, climate change will bring different changes to different areas and, in particular, Marsabit and Loita are expected to get more rain coupled with more variability.

\section{Resource curse and violent conflict in poor countries}

The resource curse, or the paradox of plenty, generally refers to the observation that countries harbouring

\footnotetext{
${ }^{1}$ Popularly, resource curse refers to a phenomenon where countries, regions or areas with an abundance of natural resources tend to show less economic growth and worse development outcomes than countries with fewer natural resources (Collier \& Hoeffler, 1998; Sachs \& Warner, 2001). In this article it refers to a situation where resource-rich areas show a high chance of (violent) conflicts.
}

abundant natural resources often lag behind in their economic performance relative to countries with limited natural resources. The explanation of this phenomenon varies widely across disciplines, and singling out a few causative variables has therefore been a very difficult exercise in a large number of studies (Brunnschweiler \& Bulte, 2009; Collier \& Hoeffler, 1998; de Soysa, 2002; Sachs \& Warner, 1997, 2001).

Even in wealthy, democratic countries, the 'paradox of plenty' can be observed when state revenues from natural resources have paralysing effects on manufacturing and economic productivity (see, for instance, Krugman, 1987). In countries with a low GDP per capita and slow growth, poverty and scarcity of natural resources are assumed to be related to violent conflict (Brunnschweiler \& Bulte, 2009). A large number of studies have been carried out to establish whether resource depletion leads to social unrest and eventually ethnic wars (Kaplan, 1994; Homer-Dixon, 1999). Especially in regions where people depend on the natural environment in production systems that rather produce for selfsufficiency than for the market, a link between poverty and violence is easily suggested (see Peluso \& Watts, 2001 for a critical review).

The resource-curse paradigm seems to be especially relevant to countries whose GDP largely consists of revenues from primary commodity exports (Collier, Hoeffler \& Rohner, 2009). When governments are unable to ensure fair distribution of returns from resources and provide basic public goods such as security, education and health financed through resource revenue, resource abundance stimulates violence, grievances, theft and looting caused by rebel groups, and even civil war (Mehlum, Moene \& Torvik, 2006). Different economic growth rates among resource-rich countries are primarily explained by how resource revenues are distributed via the institutional arrangement and fair systems of democratic governance. Their study confirms that when individuals 'colonize' the opportunities of power and resource profit offered by the state to influential leaders or politicians, natural resources push the aggregate incomes down when institutions are 'grabber-friendly'. This means that a large share of revenues earned from natural resources end up benefiting only a few individuals at the expense of the general public, usually the poor. This hints at the importance of governance and institutions in regulating the use of revenues accruing from natural resources at the national level. In the following sections we present two case studies that indicate that resource conflicts can be settled when institutional arrangements do not always lead to unlimited resource grabbing. This assumed link between scarcity 

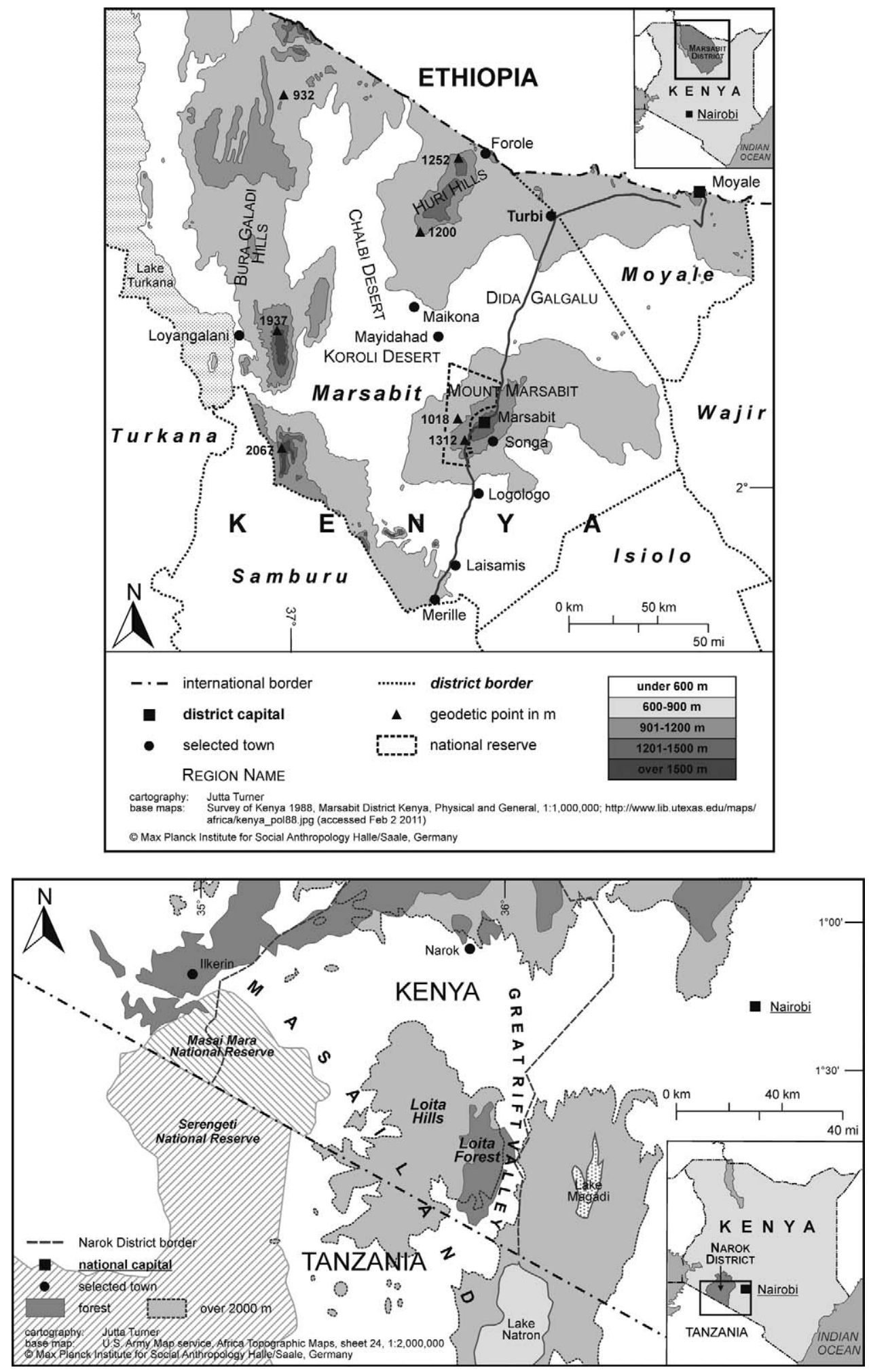

Figure 1. Location of Marsabit and Narok Districts in Kenya

of natural resources and conflict is tested and falsified in the first case study from northern Kenya, and the other from southern Kenya (Figure 1).
In the northern Kenya drylands, where livestock raiding is a widespread practice among pastoralists, the use of violence is common and part of the group-specific 
accepted codes of conduct and cultural institutions. Yet during times of drought, warring parties patch up their differences and reconcile to use scarce water resources together from limited water holes. While water is generally scarce in drylands, water abundance is extremely localized in northern Kenya, like in the other drylands. Thus, the 'value' of water as a resource in those few places increases.

The second case study deals with the paradox of plenty in a different way. In southern Kenya, pastoralists had a conflict over forest management and accessibility. Using a mix of indigenous and formal institutions, subsections of Maasai pastoralists were able to secure their access rights through a largely nonviolent settlement in court, whereby the individual resource grabbers had to withdraw their case to allow local communities to share the forest and its associated benefits according to the terms of local institutions governing natural resources. The Maasai case brings to light a pluralistic (i.e. use of traditional and 'official') form of resource regulation and access rights through collective organization of the Maasai subgroups. These groups make ingenious use of common-pool resource institutions and the provisions of the legal courts to peacefully settle differences over common property resources, despite increasing pressure on these resources due to changing climatic conditions. This result links up with other studies (Ostrom, 1990; Anderies, Janssen \& Ostrom, 2004) that find the role of local institutions crucial to resource management, avoiding a potential resource curse and instead turning it into a blessing. Thus, the example from northern Kenya is about the environmental context and the use of the institutional structures (raiding as a traditional social institution) to cope with violence. A change in environmental context such as drought activates traditional institutional structures (coping mechanism) that in turn mediate behaviour of raiders (social institution) toward cooperation. The Loita case demonstrates how non-state actors can react to social threat to a portion of their resource base (i.e. the Loita Forest as a dry season fall-back area for Maasai herders in the lowlands) in order to protect their interest without violence. While the Marsabit case is mainly about the use and outcome of social institutions of raiding, the Maasai case is about particular social institutions of age groups, Laibon and the local NGO. Both case studies show that valuable natural resources are protected and shared through peaceful collective action during periods of stress (drought, or resource capture by the state) rather through violent action. People are probably more inclined to cooperate and share resources when wealth benefits them all.

\section{Example of violent conflict from northern Kenya $^{2}$}

Northern Kenya is an economically poor and marginal region, where water, arable land and pasture are scarce resources. Their availability is highly variable, but nevertheless of vital importance to the local population. Most people here such as the Borana, Rendille, Gabra, Samburu and Dassanetch are pastoralists who fully depend on the environmental resources for their survival. Low and unreliable, rainfall determines the availability of water, pasture, crop yields and livestock production including milk and meat. Dry months typically cause stress, because all the resources that people depend on become scarcer. When the pressure on resources increases, it seems more likely that people will fight over access to these resources. Northern Kenya therefore provides a test case of climatic variability and social responses (Adano \& Witsenburg, 2004). In this context, research has been carried out on the availability of water resources and violent conflicts over several years to investigate whether there is a link between water scarcity and violence. We examined the number of violent deaths in dry and wet years in Marsabit District (including Moyale) over more than 30 years, using archival records and annual reports of government ministries. There was no evidence that drought years were more violent than wet years (Figure 2). On the contrary, there was more violence in years of high rainfall. Twice as many people (50 vs. 23) were killed in wet years as in drought years. ${ }^{3}$

We could think of a situation in which people might postpone violence until the first wet year after a drought year. But wet or average years following a drought did not show more conflict incidents and killings. In fact, fewer people were killed in wet years following droughts than in wet years in general, although the standard deviation is so high that the difference is not significant. The violence occurring in Marsabit District cannot be attributed to drought-induced scarcity of resources (Adano \& Witsenburg, 2008).

Another set of data from the same areas on seasonality and the number of killings shows yearly seasonal fluctuations in the type of violence and the number

\footnotetext{
2 This section draws heavily on work in Northern Kenya, as described in Adano \& Witsenburg $(2004,2008)$ and Witsenburg \& Adano (2007, 2009).

${ }^{3} \mathrm{~A}$ 'drought year' is defined as a year when the annual rainfall is 700 $\mathrm{mm}$ or less. The rainfall was measured on Marsabit Mountain, which receives a higher amount of rainfall than the surrounding lowlands (Adano \& Witsenburg, 2008: 229, 1161-66).
} 


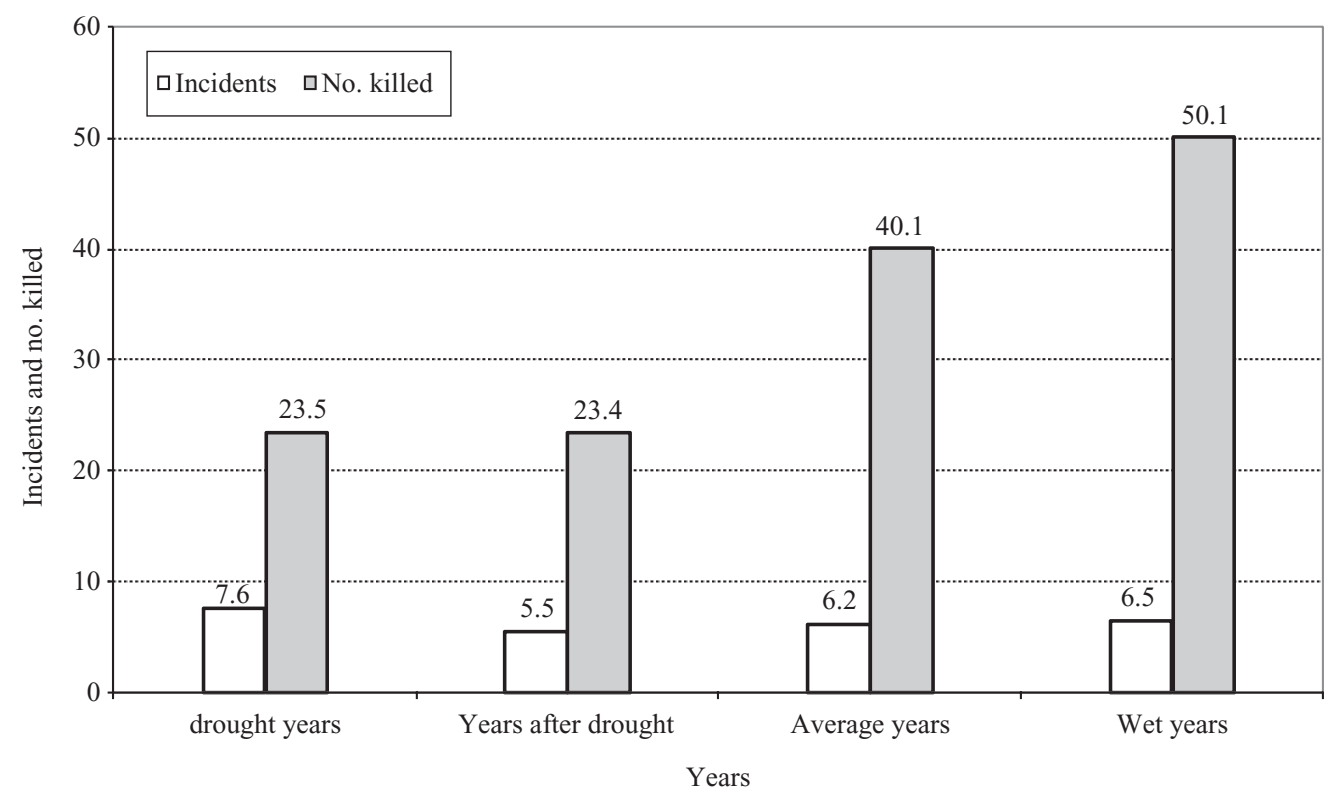

Figure 2. Average number of conflict incidents and killings in dry, average or wet years, 1929-99

'Drought year' is rainfall $\leq 700 \mathrm{~mm}$; 'year after drought' is rainfall $<700 \mathrm{~mm}$; 'average years' is rainfall $701-850 \mathrm{~mm}$; 'wet years' is $\geq$ $851 \mathrm{~mm}$ rain.

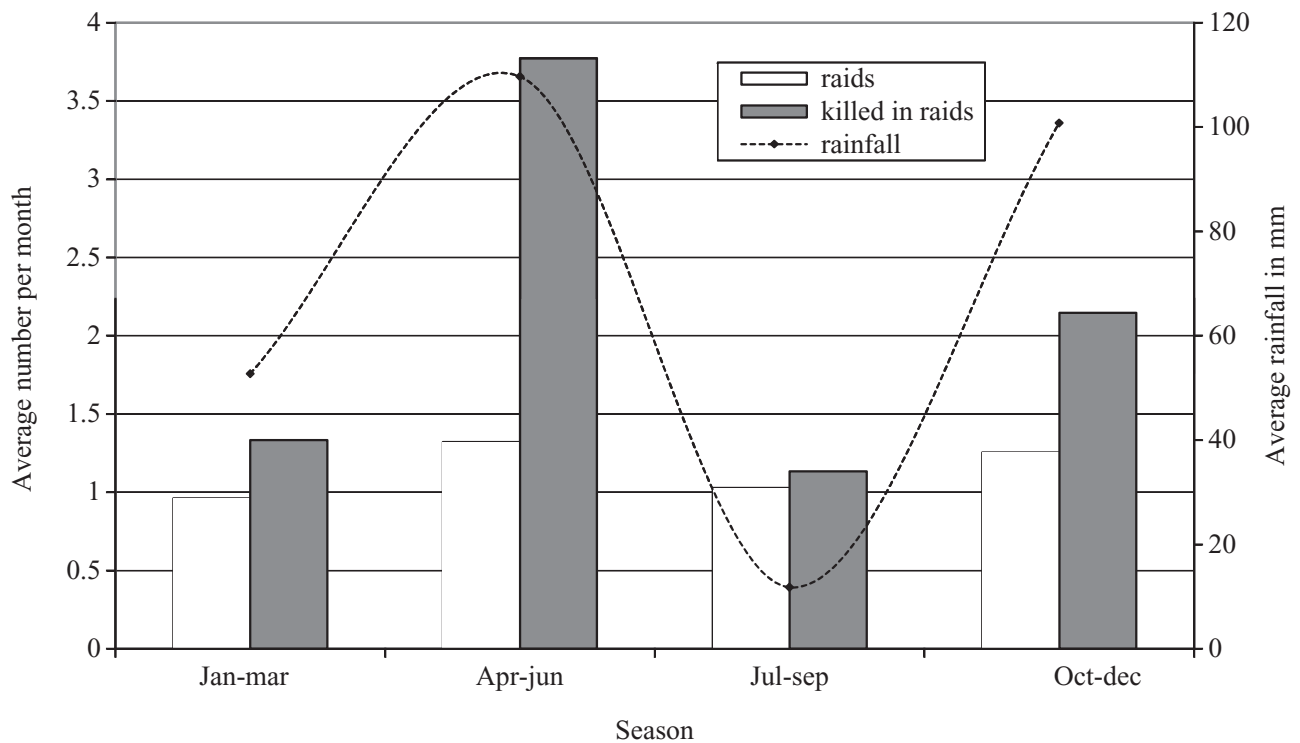

Figure 3. Seasonal fluctuations in killings and rainfall, combined averages per season, 1950-94

Source: Witsenburg \& Adano (2009: 525).

of killings. Figure 3 shows the relationships between seasonal human killings and rainfall patterns based on information from archival records of the Security Committee. We only took years for which we had 12 months of both rainfall data and the number of killings. We divided the year into four seasons based on a bimodal rainfall pattern (long rain March-May and short rain October-December), with two dry seasons, in northern Kenya. Figure 3 also shows the sum of all people killed and those killed in raids, per month, combined in three-month seasons. The data only include interethnic violence. Intragroup killings are excluded from these figures because data are not available from the records. 
In January-March relatively few people are killed in raids. The number of violent raids shoots up in the wet season of April-June, but then decreases during the dry period in July-September. Raid-related violence again goes up in the wet season of October-December. Generally, most violent killings in this region occur during livestock raids. Only one person per month on average is killed in other fights. This figure remains stable over the year, except for the dry season of July-September when other violent killings shoot up. During the July-September season there still is a very high murder rate that is not livestock-related. A closer look reveals that these months were particularly violent in the years 1963 (46 killings), 1992 (24 killings) and 1994 (49 killings). In 1963, Kenya achieved independence and the secessionist Shifta War started, so this was a very violent year in the whole of the northern region. 1992, when multiparty democracy was introduced, was a very violent year all over the country. In 1994, there was a violent ethnic conflict on Marsabit Mountain between the Borana and the Burji. These incidents were solely politically motivated confrontations.

\section{Violence as enacted individual behaviour and collective choice}

The finding that more people are killed in raids during the wet season may seem strange to outside observers, but to the local people involved it was simply explained by their notion of rational behaviour. In northern Kenya people do not necessarily engage in violent conflict in general, and more specifically not over water resources. Especially during droughts people are more inclined to keep the peace, to cooperate and to use wells together. Even though wells can be individually owned or owned by a specific clan, the water inside is a common property resource and carefully managed by a number of people. When a drought is expected, warring pastoralists usually reconcile in order to use water and pasture together. Violent livestock raiding is mostly carried out during the wet season. The animals are stronger and fatter then, and the vegetation and surface water are more readily available, which is necessary during a long trek away from the area where the raid took place. The vegetation is also thicker, which makes it easier to hide after an attack. Raiders usually have to trek long distances, for which the animals should be fit and strong. Raiding is especially common during the rainy season because rain washes away tracks, which increases the chance of escaping with the raided livestock. Rainy seasons in pastoral areas are usually times of relative abundance, not only of pasture, water or milk. There is also a labour surplus, which makes it easy for young men to engage in raiding.

As Peristiany (1939) notes in the 1930s for the Kipsigis, raids are carried out under enduring hardship in the bush and using every tactic of enemy engagement such as sending out spies, occupying all the strategic positions to ward off any forthcoming help for those attacked and attack before daybreak. In 2008, one informant narrated how raids are normally organized. The people who participate in the raid come from all clans to avoid the risk that one clan is decimated when the attack fails. Most age groups are also represented. Raiders who are too eager to attack because of anxiety and lack of sleep might be advised not to join the group at the place of the enemy on the actual day of attack. The party needs some calm and experienced men who do not make disastrous errors during the attack. Before the actual raiding day, the group decides which animals to take and also obtain tags such as white bark of a tree to differentiate themselves from the enemies (Wosori Damballa, ${ }^{4}$ Marsabit, July 2008). Otherwise the group may end up killing each other in the commotion, especially in the dark when it is difficult to differentiate people.

The same informant stated that such big raids are rare nowadays, as Peristiany (1939) also observed in the 1930 s among the Kipsigis community in western Kenya. According to the informant it is hard for such a large group of men to leave the herds for so long a period. In times of hardship such as dry seasons or during droughts there is no labour surplus as heavy manpower is required by the herding families. This narrative clearly confirms the notion of both individual or collective action in violence as rational behaviour, and the phenomenon of cooperation to overcome climatic stress rather than to indulgence in violent behaviour.

A number of other interesting descriptions explain the practice of violent livestock raiding in a similar way. For example, Mieth (2006), Eaton (2008) and de Vries (2007) have independently surveyed cattle raiders in the western Pokot area for their motives and raiding practices and their perceptions of insecurity. Like-minded small groups organize raids of which the whole ethnic group is not necessarily always informed (Peristiany, 1939; Almagor, 1979). Approval of elders was often not sought. A raid should therefore not simply be called 'ethnic warfare' or 'ethnic clash', since it is not the ethnic group as a whole or its leaders that is involved in

\footnotetext{
${ }^{4}$ The names have been changed in order to maintain the anonymity of the interview participant.
} 
violence. In addition, raiding parties consist of a small selection of warriors who strive to achieve social standing in the pastoral society. They are often young, strong and certainly not among the poorest. They value group respect, bravery and earning a name among peer groups, and defend or protect their own group's territorial grazing areas. To be seen as a hero, and gaining the image of a fierce cattle raider, is of immense importance to the warriors. According to Pokot informants (Mieth, 2006) a raider goes to the war front for appreciation of others, to prove he is a hero and to earn praise for killing an enemy. A warrior who proves to have poor raiding skills is teased without mercy. A raider who goes to raid and then runs away from the raided party is called a coward and people will compose and sing songs to humiliate him and his family.

In Pokot, like in other drylands, situations of insecurity and keeping a region unsafe serve the raiders well. The raiders do not necessarily have the same interests as those who prefer a secure environment and a peaceful community. Raiding is training for survival in insecure areas. Understandably, finding a partner who is able to face up to a fight is a matter of securing the basic survival for girls. Indeed, spaces of insecurity have for a long time served such communities in their struggle against government control, as the following incident from the colonial records shows. The colonial administrator from 1963 in northern Kenya describes an incident on the 15 June, when a 35-strong raiding party attacked a Samburu hamlet and killed and mutilated about 24 people. Only two raiders were wounded during the attack, and the rest looted and made off with all the cattle owned by the village. One policeman killed two of the attackers later, but the remainder of the raiders made off. This raided hamlet was situated in the extreme south-west of Marsabit District, in country difficult to access. Only 24 hours later news of the incident reached Loiyangalani, so that Kenya Police and Tribal Police could be deployed in an attempt to intercept and trace the offenders. ${ }^{5}$

This incident depicts the livestock raiding practice as something of a ritual to humiliate and dehumanize the enemy. The raid described here took place in a very remote area, which was not only difficult to access but also made it difficult for the police to intervene. This is a typical geographical feature necessary for a successful raid. The raiding party consisted of at least 35 men,

\footnotetext{
${ }^{5}$ Marsabit District Security Committee (DSC) Files; C. Sec. 2/1/5/ IV/494 (1963: 2).
}

which is partly indicative of a collective action that needs organization and mobilization. The raiding party only lost two members to the police while the rest made off with their loot. The advantage of raiders over the police is that they know the landscape better and are usually better trained in trekking through rough country. The brutality of the attack, during which not only were livestock taken but the bodies of men, women and children alike were mutilated is a reminder that this event is not only about resource capture. The year 1963 (with $1,235 \mathrm{~mm}$ rainfall) was not a dry year, and the $1960 \mathrm{~s}$ were not a period of drought (Adano \& Witsenburg, 2004: 91); it was even one of the wettest decades in the history of recorded rainfall in the district.

\section{On insecurity, poverty and geographical context}

The number of people who were killed in interethnic violence in Marsabit and Moyale comes to an average of about 25 persons per 100,000 inhabitants per year from 1949 to 1959 (KHRC, 2000; Witsenburg \& Adano, 2009) and 36 persons per 100,000 inhabitants each year from 2002 to 2008 . The increase could be a result of a more efficient method of counting and reporting, and also worsening tension between ethnic groups related to the government's ardent top-down approach to the introduction of new boundaries. New administrative boundaries have cut off former natural resources for neighbouring ethnic groups, in regions where resources were shared before. With this high killing rate, the region comes close to being as insecure as urbanized areas in the world, such as Nairobi (77), Washington, DC (60), or Pretoria (43). ${ }^{6}$

Dryland regions generally bear the image of being unsafe. It is not a coincidence that geography and social problems converge here; remote and marginal areas are attractive environments for certain types of violence and criminal behaviour. This is in line with Fleisher (2000), who observed that in southern Kenya no effective opposition to cattle raiding exists among herding communities because of recurring clan warfare. While alluding to a similar ethnographic account in western Kenya, Anderson (1993: 865) observes that among the Kalenjin community, allegedly, the cattle-rustling activities of the moran (a Maasai word for warriors) are considered rather a 'sport' and not a crime. This kind of view locally legitimizes the practice of cattle raiding and

\footnotetext{
${ }^{6} 1997$ figures (Barclay \& Tavares, 2002). The Marsabit figures are underreported, because these only include violent deaths as a result of interethnic fights or raids (Gimode, 2001).
} 


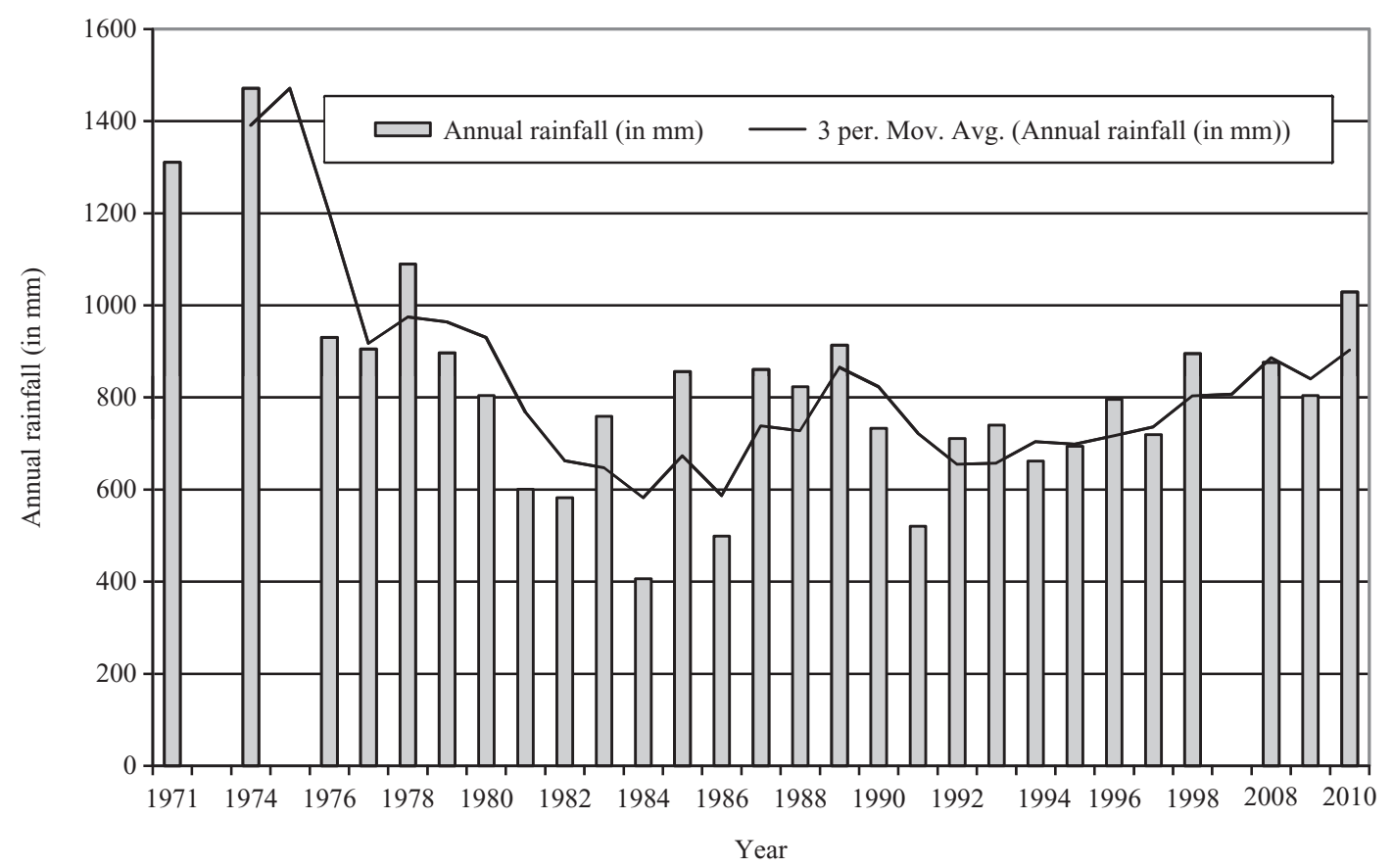

Figure 4. Rainfall trend for Narok, south western Kenya

functions as a training opportunity for young men to try out and perfect their raiding, and thus thieving skills. The culturally endorsed and socially rewarded raiding behaviour thus reinforces a climate of insecurity and lawlessness that is necessary to raid effectively, especially against certain groups in the absence of effective law enforcement. Thus it proves true that 'War is good for thieving' (Fleisher, 2000: 750) or that 'opportunity makes the thief (Felson \& Clarke, 1998).

\section{Ingenuity in social institutions}

The conflict in the Loita Maasai area of Narok District, southern Kenya, is a very illuminating one for our argument. The contested resource is the Loita Naimina Enkiyio Forest (LNEF or Loita forest hereafter), a source of water, dry-season grazing area and natural forest on the edge of the Great Rift Valley. The forest is used by the Loita Maasai, but coveted by the Purko Maasai, living to the north but still inside Narok District. In many similar cases in Kenya over the last few decades, ethnic groups or subethnic groups compete or sometimes fight over key resources for access, use of revenues or competing claims over ownership rights. Water resources and dry-season grazing in pastoral areas are the natural capitals triggering conflict when issues of access, usage rights and ownership are at stake. The Loita forest can be seen as a scarce resource, for which ethnic groups compete.
However, due to its character, size and fixed location, and given the context of the Kenyan economy and political constellation, the Loita forest is also a resource for national actors. Not only the ethnic groups, but also their ministers want access for personal wealth. These two conflicts merge, and we describe the process chronologically.

The context is typical for Kenya and many other countries in Africa. The Kenyan population has increased rapidly, from 10.9 million people in 1969 to 38.6 million in 2009 (KNBS, 2010) and shows no sign of stabilizing soon. In Narok District, population growth has been even more rapid, with about a seven-fold increase over the same period. Already among the most densely populated semi-arid areas of Kenya, the pressure on land in Narok District has increased further with commercial wheat production taking large tracts of land away from use by pastoral producers.

In addition, climate change seems to have begun impacting this region too, and long-term rainfall figures show a decline in the western part of Kenya since the early 1970s, which is supported by (still scanty) data on precipitation in Narok and nearby Kajiado Districts. Droughts have become lengthier, the rainfall within the rainy season more variable. Figure 4 shows a clear increase in rainfall particularly in recent years in Narok District, but as this seems to coincide with higher temperatures and subsequent higher evapo-transpiration, the effect is a decline in the moisture balance. 
The Loita forest is a fall-back area for the Loita Maasai and the neighbouring Purko alike and is therefore increasingly important for the survival of the pastoral production system. As a consequence, there is a slow migratory movement towards the forest, and the potential for conflict over future access rises. Although the previous case can be characterized as a study of short-term conflicts over seasonally scarce resources, this case provides a longer-term perspective on scarcity due to population growth, climate change and relative resource scarcity.

The Loita forest is set between the Nguruman-Magadi escarpment bordering Kajiado District to the east, the Osupuko Oirobi (Purko Maasai land) to the north, the border of Tanzania to the south and the rangelands towards the Maasai Mara National Game Reserve, the most famous tourist destination in Kenya, to the west. The Loita Maasai area encompasses a variety of ecosystems, of which the grasslands at lower altitudes and the Loita forest at higher altitudes form the dominant features. The forest is one of the few un-gazetted (i.e. with no legal restrictions of local access) and largely undisturbed indigenous forests in Kenya (Njogu, 2004). The Loita Hills, with the Loita forest, are the main water catchments for the surrounding lowlands. The forested highlands receive, on average, an annual rainfall of between 700 and 1,200 $\mathrm{mm}$, while rainfall in the surrounding lower rangelands is at $600-700 \mathrm{~mm}$. The wetland areas and, during extreme droughts, the upland semi-deciduous and mixed species forests form the ultimate fall-back grazing areas (Maundu et al., 2001; Dietz, 1996). During the extreme drought of 2005-06, almost all Loita Maasai herds were grazed within the forest.

The Loita Maasai community has an indigenous tenure system that gives use rights of natural resources to various groups in and outside the community. The Loita forest is a common-pool resource shared by many users for grazing, traditional cultural ceremonies, medicinal plants, construction materials and as a source of water. Certain resource types and uses are strictly controlled, while others are more freely accessible. For example, the forest has considerable spiritual and emotional value. Many transition rites and other important rituals and ceremonies take place in the forest, such as the age-set initiation and cleansing rituals and fertility blessings for women who are unable to give birth (Maundu et al., 2001). Because of all these usage practices, the Loita community sees the spiritual leader, the Laibon, who performs his ritual duties at specific sacred sites in the forest, as the custodian of the forest. He is central to forest conservation. The Laibonok (plural of Laibon) have unlimited rights and access to the forest to provide divine services to the wider Maasai society rather than for their own private gains (Karanja, Tessema \& Barrow, 2002).

The Loita community shares the grazing land with the neighbouring Purko Maasai community and the Loita Maasai of Tanzania. As long as the boundaries of the territories are undisputed and resource use is mediated and regulated by customary laws, the sharing of seasonal pastures by the different Maasai sections poses no threat to any section. It is a reciprocal right used during emergencies and regulated by customary laws. In this case and depending on the season, the Laibonok and the herders have overlapping rights to use the forest, for cultural ceremonies and grazing, respectively (Ole Siloma \& Zaal, 2005).

However, there has been a slow and continuous migration of Purko Maasai towards the Loita highlands for many decades now, starting early in the colonial period as part of early 20th-century upheavals. ${ }^{7}$ The Purko population, being more numerous and living in slightly drier areas of Narok, had for some time been invading the forest and Loita area. The valleys leading into the forest were, and still are, slowly being occupied by Purko Maasai. This slow intrusion into Loita Maasai ancestral lands and into the forest is resented by the Loita Maasai who are frequently in conflict with the Purko migrants over illegal use of the forest, such as charcoal burning and timber production. The relationship between these two groups has been 'not cordial', to quote an interviewee. Yet, the Purko Maasai who live in those valleys maintain that as long-time residents they have the right to use the forest, especially when they claim access on the basis of belonging to similar clans that exist within both the Loita and Purko Maasai communities.

\section{Collective rights versus rent-seeking behaviour over the Loita forest}

The Loita forest is located on trustland (Maundu et al., 2001), which means it is entrusted to the local County Council of Narok and managed in accordance with the Trust Land Act (Cap. 288 of the Laws of Kenya). The

\footnotetext{
7 The pressure on the grazing resources in Narok and Kajiado Districts had increased considerably due to the displacement in two successive moves of the Maasai community from the Central Kenya Highlands such as Laikipia, when white ranchers, supported by the colonial government, appropriated these areas. Within a decade, the population in Narok and Kajiado Districts almost doubled.
} 
potential of the forest as a conservation area and tourist site has been a source of conflict among the different interest groups, notably the local community and the County Council. The local balance of power was further complicated when one of the most prominent leaders of the Purko Maasai, a minister in the Kenyan Cabinet, tried to generate support among local elected leaders (councillors of the Divisions of Narok District of which Loita Division is only one) to gazette the forest (i.e. restrict local access) and turn it into a forest reserve and national park. This would have expelled the present local users from the forest and would have allowed a few entrepreneurs to build lodges and generate private revenues from tourism. The Minister had a number of lodges in the neighbouring Maasai Mara District, and thus he clearly had the business experience and opportunity to take over the forest and build tourist facilities there.

The Purko minister had allied himself with a Loita Member of Parliament and a Loita councillor. The three men seemed to have agreed that the Loita forest was to be demarcated for gazettement, and the councillor drafted a letter incorrectly writing that the Loita people agreed to the gazettement decision. The intention to gazette the forest was communicated to the Minister for Environment. ${ }^{8}$ This minister himself had benefited from a similar procedure, when a neighbouring group ranch had been demarcated and leased to him when he was still a Member of Parliament for a neighbouring constituency.

However, resistance began to build up, and the director of a regional development project, the Ilkerin Loita Integrated Development Project (ILIDP), ${ }^{9}$ called a meeting of the Loita Council of Elders (LCE). The LCE had been installed earlier with assistance from the ILIDP project to organize the community. The LCE was constituted with the intention to have a broad representation of the population in the council. An important part of the intervention strategy of the ILIDP, this participation did ultimately lead to more relevant project work. Now,

\footnotetext{
${ }^{8}$ This is according to Kenyan law. As stipulated in the Forests Act (Cap. 385), a minister has among others the powers, by notice in the Gazette, to either declare or alter the boundaries of a forest (Government of Kenya, 1982).

${ }^{9}$ ILIDP was started in 1968 as the initiative of a local Loita leader and a Dutch Catholic Missionary. Support came from Dutch Catholic development NGOs. The conflict coincided with a period in development thinking in general, and within this organization in particular, that promoted empowerment, advocacy and networking as strategies for development. Two decades after it was founded, ILIDP was confronted with the Loita forest conflict which a decade later was successfully solved.
}

however, it also linked the population that started to resist the gazettement with the ILIDP, the senior elders, the elected councillors, the Laibonok, the development officers in the government, and some women and youth groups. Some of the LCE members were also on the Board of ILIDP, for example. The Narok County Council (NCC) was acknowledged at the time as being entirely justified in managing the forest and deciding on its future use, as the council kept all un-demarcated and un-gazetted land in trust for the benefit of the local population. Even so, the earlier loss of access to the Maasai Mara and Kamororo group ranch referred to above (Zaal \& Ole Siloma, 2006), which was previously allowed by earlier council members and had benefited the Minister for the Environment, had made the ILIDP and LCE very concerned. Other similar cases included the destruction in previous years of the Mau forest, which is also a Narok forest area under NCC trusteeship.

The LCE resolved to organize a broad resistance movement. The Minister for Environment subsequently changed his mind and agreed to assist the Loita community. A lawyer established the Loita Naimina Enkiyio Conservation Trust (LNECT), a registered entity with the primary duty to protect and manage the forest and its associated ecosystem heritage held in trust by the local Narok County Council.

Of course this merits the question whether, as a nonlegal institution informally representing the population, the LCE was in a position to organize resistance against a formal and lawful institution such as the Narok County Council, which had the responsibility by law to decide on the future of the forest. ${ }^{10}$ However, the timing of the conflict is worth considering in the context of Kenya's history. The first truly democratic elections were to be organized in 1992, and at the present stage of the conflict, the NCC could hardly be considered truly

${ }^{10}$ In a recent landmark ruling, the African Commission found the Kenyan Government guilty of violating the rights of the Endorois community living around Lake Bogoria by unlawfully evicting them from their ancestral land in order to create a protected area (CMRD, 2010). Two of the views of the African Commission in support of the ruling have relevance to the Loita example. First, the recognition that the state has a duty to ensure that indigenous sacred places, linked to cultural beliefs and practices, and ceremonial acts that are central to freedom of religion, be preserved, respected and protected. Second, the State is to apply international law concerning the protection of indigenous people's collective rights to lands and natural resources as a community, even in the absence of official title deeds to a particular territory. These aspects would support the Maasai community in defending their ownership rights to the local resources. 
democratic in a representative and multi-party democratic meaning of the word. The conflict had erupted meanwhile, and protesters and those who wanted to appropriate the forest confronted each other violently. On one occasion opposite the ILIDP facilities in Narok Town, some people were killed when police started shooting prematurely (Dietz, 1996).

The Loita Naimina Enkiyio Conservation Trust (LNECT) took the matter of the appropriation of the forest to court. In this court case, many found it very difficult to choose sides. Conflicting points of view became apparent within the Loita community (groups were divided along clan lines according to their Purko or Loita background, and old and young also often disagreed).

So far, traditional institutions (age groups, Laibonok) and modern organizations (the ILIDP, LCE and LNECT) had joined forces to fight against the Purko and their Minister for control over the Loita forest. The national elections gave the opportunity for both factions to present their views and drum up support. Within the Loita community, councillors supported by the ILIDP faction were better positioned to win this election. One item that came up for public scrutiny was the letter that the Loita councillor had written stating that the Loita people were supportive of the gazettement. This and many other issues ultimately led to the political demise of the councillor who lost the election. A new Loita councillor took charge, split his constituency ${ }^{11}$ and had four other Loita councillors elected. This considerably increased the representation of Loitans on the Narok County Council, and when a Loitan was elected as chairman of the NCC, the political clout of the Loita community in the NCC had improved. The power balance had shifted between the national elections of 1992 and the last years of the 1990s. The earlier councillor and the minister lost control in Narok District. On the instigation of the new Loita councillors and the chairman of the NCC, the case was withdrawn from court. The Loita forest did not gain the status of national park, but remained open for use by the Loita community. A decade-long conflict had ended.

The Loita forest case shows that individual actors can be quite influential in how conflicts start and develop, but the actual course that conflicts take and play out is ultimately determined by larger forces. The underlying tension between Purko and Loita Maasai, dating back

\footnotetext{
${ }^{11}$ This was implemented after discussions with the relevant authorities in Kenya at national level. Support was sought from the Office of the President which influenced this decision.
}

to well before the colonial period but strengthened by colonial policies of population displacement and boundary establishment of the Districts in which they lived, proved to be a fertile ground both for Purko players to gain control and for Loita players to resist this usurpation. More modern sets of legal entities, both elected and non-elected, have been added to this sphere of conflict. The present status quo could not have been reached without a modern judicial institution, used successfully by the Loita Maasai through legally authentic institutions such as development projects and a re-established informal Council of Elders. This fascinating case shows that old ethnic and subethnic conflicts between Maasai groups over a key resource can be peacefully contained through complex and unexpected alliances.

The Loita forest case shows that with increasing pressure on resources due to population growth and drought impacts of climate change, there are opportunities for moderation of potential conflicts. This evidence offers an important starting point for recognizing the importance of local knowledge and norms in crafting cooperative, nonviolent solutions in collective actions. This case also shows that old institutional arrangements can link up with new institutions and organizations to achieve this moderation. Within a changing and interconnected world, new threats in the form of commercial interests arise. To counter this, new local-level alliances are formed to deal with potential conflict over a common-pool resource, turning resource abundance into a blessing.

\section{Spaces of violence}

Violence itself creates a space of insecurity and lawlessness. It attracts individuals who thrive in insecure environments where there is little or no effective state control (Schlee, 2002, 2008; Salih, 1999). Insecurity also prevents the entry of peaceful individuals, firms and organizations to settle or invest locally. In addition, flows of people, goods, information, money and weapons involved in violence either directly or indirectly are generated. Insecurity transcends the region and makes situations conducive for thieving and other predatory forms of involvement of outsiders (Felson \& Clarke, 1998).

Borders play a role in this process. In a raid, tracing raided livestock is more difficult once it has crossed a border. In a globalized world, rebel or guerrilla movements with international support networks look for sparsely populated areas for their training camps and their trekking routes. They also provide recruitment grounds for unemployed youths whose bravery and courage can 
be exploited and cultivated in places far from the centre. In addition, violence and insecurity reduce people's capacity to cope with drought, to educate their children properly, to market their goods and to use land intensively and effectively. As a result, insecurity and violence deny components of economic and other forms of development and the opportunity to respond to peoples' needs, thus preserving the state of poverty. Insecurity and conflict in drylands have hampered provision of and access to basic public services such as health care and education. In the words of Sen (1999), these issues obstruct the development of people's capabilities. The negative economic consequences therefore have wider spillover effects, and the relationship between violence and poverty centred on exactly these issues. It is not that poor people are more likely to use violence. But, a situation of insecurity denies new and innovative ideas the chance to develop, which in turn leads to loss of opportunities for economic growth.

A study of violent relationships between growing numbers of humans and their struggle for access to natural resources influenced by climate change should not $a$ priori have a structural or an agency approach. A structural approach tends to ignore all the personal decisions and the opportunistic behaviour of individual actors, while an agency approach does not take pathwaydependent structural variables into account. As the case studies described above clearly show, there is a need to combine both aspects.

Our conclusion is that the wetter the season, the more people are likely to die in violent livestock raiding. In other words, more conflicts and killings take place in wet season times of relative abundance, and less in dry season times of relative scarcity, when people reconcile their differences and cooperate. During drought periods, pastoralists in northern Kenya deploy social institutions that mediate agency toward cooperation and guarantee access rights to resources (water) for all, thereby reducing violent conflicts. Remoteness and inaccessibility of the terrain weaken government initiatives to provide adequate security, but local arrangements moderate conflicts when scarcity peaks. The absence of overt violent conflict in Marsabit is clearly not due to lack of scarcity, which is a common feature of marginal and deteriorating environmental conditions.

In the Loita forest case, a fast-growing pastoral population mobilized against neighbouring ethnic groups with high-level linkages to the national government in order to secure access to a typical common property resource that was of vital importance to their livelihood. Individual and group actors made clever use of institutions to win a conflict over resources nonviolently. The Loita forest did not become a resource curse, because a mixture of old and new institutional arrangements prevented it from being grabbed by a collusion of competing pastoralists and a few rent-seekers. The range of benefits from the forest's functions and financial revenues are now used and shared by a large number of producers. The results reveal a rare insight into the importance of hybrid customary-cum-legal institutions and ingenuity as to whether or not a common-pool resource becomes a curse. Therefore, human agency ultimately determines whether natural resources turn into a curse, but we need the historical contextual analysis of institutional structures to inform us about the potential threats and opportunities. Equally, in a scenario of climate change when the potential threats to the environment are known, coping largely depends on the institutional devices invoked by local actors. When northern Kenya indeed receives more rain in the coming century, as predicted by the IPCC report, we may expect more violence in the short term. However, we may also expect the technological and institutional change and flourishing ingenuity that usually ensue from higher population numbers and increased scarcity. When south-western Kenya indeed becomes dryer, we may expect increased competition for forest resources. Yet, institutional development may address the need for conflict resolution. Inaccessibility, remoteness and marginality may be reduced under such a scenario, and this will make the environment a less attractive place for violent behaviour.

From each of the two case studies emerges the significant role of institutions, be they traditional or 'official', in preventing avoidable conflicts and allowing reconciliatory situations to prevail within competing interest groups and between rivalry communities in Loita and Marsabit. The turning of natural resources into either a blessing or a curse depends on the community shaping and using its own institutional apparatus, and doing this within its historic institutional context. Thus, in areas where certain key resources are either scarce or abundant and climate is changing, the local institutional arrangements can be instrumental in moderating resource-related conflicts.

\section{Replication data}

The dataset and do-files for the empirical analysis in this article can be found at http://www.prio.no/jpr/datasets.

\section{Acknowledgements}

This article was first presented at the Third European Conference on African Studies, 4-7 June 2009, Leipzig, 
at the panel: 'Poverty and Peace in the African Countries: Debate on the Possible Correlations'. We thank the panel organizer Cristina Rodrigues Udelsmann and the participants, particularly Marleen Dekker, for their valuable comments. Earlier versions of the article have also been presented at the Max Planck Institute's Research Colloquium, 7 July 2010 and 'Integration and Conflict' retreat, 5-9 September 2010. We acknowledge with thanks useful suggestions of Aksana Ismailbekova, John Eidson, Joachim Görlich, Günther Schlee, Nathiel King and Zahir Abdal-Kareem, and four anonymous reviewers and Associate Editor Nils Petter Gleditsch for their constructive criticisms and thorough comments. Many thanks also go to Jutta Turner for designing the map and Anja Sing for editing the article. However, the usual disclaimer applies.

\section{References}

Adano, Wario R \& Karen Witsenburg (2004) Surviving pastoral decline: Pastoral sedentarisation, natural resource management and livelihood diversification in Marsabit District, Northern Kenya. PhD dissertation, University of Amsterdam.

Adano, Wario R \& Karen Witsenburg (2008) Pastoral Sedentarisation, Natural Resource Management and Livelihood Diversification in Marsabit District, Northern Kenya. Lewiston: Edwin Mellen.

Almagor, Uri (1979) Raiders and elders: A confrontation of generations among the Dassanetch. In: Katsuyoshi Fukui \& David Turton (eds) Warfare among East African Herders. Senri Ethnological Studies (3). Osaka: National Museum of Ethnology, 119-144.

Anderies, J Marty; Marco A Janssen \& Elinor Ostrom (2004) A framework to analyze the robustness of social-ecological systems from an institutional perspective. Ecology and Society 9(1): 18-34.

Anderson, David M (1993) Black mischief: Crime, protest and resistance in colonial Kenya. Historical Journal 36(4): 851-877.

Barclay, Gordon \& Cynthia Tavares (2002) International Comparisons of Criminal Justice Statistics 2000. London: Research Development and Statistics Directorate, Home Office (http://rds.homeoffice.gov.uk/rds/pdfs2/hosb502. pdf).

Boko, Michel; Isabelle Niang, Anthony Nyong, Coleen Vogel, Andrew Githeko, Mahmoud Medany, Balgis Osman-Elasha, Ramadjita Tabo \& Pius Yanda (2007) Africa: Climate change 2007. In: Martin L Parry, Osvalda F Canziani, Jean P Palutikof, Paul J van der Linden \& Clair E Hanson (eds) Climate Change 2007: Impacts, Adaptation and Vulnerability, Working Group II contribution to the Fourth Assessment Report of the Intergovernmental Panel on Climate Change. Cambridge: Cambridge University Press, 433-467.
Brunnschweiler, Christa \& Erwin Bulte H (2009) Natural resources and violent conflict: Resource abundance, dependence and the onset of civil wars. Oxford Economic Papers 61(4): 651-674.

Buhaug, Halvard (2010a) Climate change not to blame for African civil wars. PNAS 107(38): 16477-16482.

Buhaug, Halvard (2010b) Reply to Burke et al. (2009): Bias and climate war research. PNAS 107(51): E186-E187.

Buhaug, Halvard; Nils Petter Gleditsch \& Ole Magnus Theisen (2008) Implications of Climate Change for Armed Conflict. Report to World Bank. Washington, DC: World Bank (http://siteresources.worldbank.org/INTRANET SOCIALDEVELOPMENT/Resources/SDCCWorking Paper_Conflict.pdf).

Burke, Marshall B; Edward Miguel, Shanker Satyanah, John A Dyekema \& David B Lobell (2009) Warming increases the risk of civil war in Africa. PNAS 106(49): 20670-20674.

Carius, Alexander (2009) Climate Change and Security in Africa: Challenges and International Policy Context. UN Office of the Special Adviser on Africa, Berlin, December. CMRD (2010) Landmark Decision Rules Kenya's Removal of Indigenous People from Ancestral Land Illegal. Centre for Minority Rights Development (http://www.minorityrights.org/9587/ press-release/landmark-decision-rules-kenyas-removal-ofindigenous-people-from-ancestral-land-illegal-html).

Cole, John (1996) Geography of the World's Major Regions. London \& New York: Routledge.

Collier, Paul \& Anke Hoeffler (1998) On economic causes of civil war. Oxford Economic Papers 50(4): 563-573.

Collier, Paul; Anke Hoeffler \& Dominic Rohner (2009) Beyond greed and grievance: Feasibility and civil war. Oxford Economic Papers 61(1): 1-27.

de Soysa, Indra (2002) Ecoviolence: Shrinking pie, or honey pot? Global Environmental Politics 2(4): 1-34.

de Vries, Kim (2007) Identity strategies of the agro-pastoral Pokot: Analysing ethnicity and clanship within a spatial framework. MA thesis. Amsterdam: University of Amsterdam.

Dietz, Ton (1996) Entitlements to Natural Resources: Contours of Political Environmental Geography. Inaugural speech, University of Amsterdam. Utrecht: International Books.

Eaton, Dave (2008) The business of peace: Raiding and peace work along the Kenya-Uganda border. (Part 1) African Affairs 107(426): 89-110; (Part 2) African Affairs 107(427): 243-259.

Felson, Marcus \& Ronald V Clarke (1998) Opportunity makes the thief: Practical theory for crime prevention. Police Research Series Paper (98). London: Policing and Reducing Crime Unit, Home Office.

Fleisher, Michael L (2000) Kuria cattle raiding: Capitalist transformation, commoditization, and crime formation among an East African agro-pastoral people. Comparative Studies in Society and History 42(4): 745-769.

Gimode, Edwin (2001) Anatomy of violent crime and insecurity in Kenya: The case of Nairobi, 1985-1999. Africa Development 26(1-2): 295-335. 
Gleditsch, Nils Petter (1998) Armed conflict and the environment: A critique of the literature. Journal of Peace Research 35(3): 381-400.

Government of Kenya (1982) The Forests Act Chapter 385 (Cap. 385). The Laws of Kenya. Nairobi: Government Printers.

Halden, Peter (2007) The Geopolitics of Climate Change: Challenges to the International System. Stockholm: Swedish Defence Research Agency.

Homer-Dixon, Thomas (1999) Environment, Scarcity and Violence. Princeton, NJ: Princeton University Press.

Human Impact Report (2009) Climate Change: The Anatomy of Silent Crisis. Human Impact Report (53). Geneva: Global Humanitarian Forum.

IPCC (2007) Climate Change: Synthesis Report Contribution of Working Groups I, II and III to the Fourth Assessment. Geneva: Inter-Governmental Panel on Climate Change.

Kahl, Colin (2006) States, Scarcity, and Civil Strife in the Developing World. Princeton, NJ: Princeton University Press.

Kaplan, Robert (1994) The coming anarchy: How scarcity, crime, overpopulation and disease are rapidly destroying the social fabric of our planet. Atlantic Monthly 273(2): 44-76.

Karanja, Francis; Yemeserach Tessema \& Edmund Barrow (2002) Equity in the Loita/Purko Naimina Enkiyio Forest in Kenya: Securing Maasai Rights to and Responsibilities for the Forest. Nairobi: IUCN/World Conservation Union.

KHRC (2000) The Forgotten People Revisited: Human Rights Abuses in Marsabit and Moyale Districts. Nairobi: Kenya Human Rights Commission.

KNBS (2010). 2009 Population and Housing Census Highlights. Nairobi: Kenya National Bureau of Statistics.

Krugman, Paul (1987) The narrow moving band, the Dutch disease and the competitive consequences of Thatcher: Notes on trade in the presence of dynamic scale economies. Journal of Development Economics 27(1-2): 41-55.

Leff, Johan (2009) Pastoralists at war: Violence and security in the Kenya-Sudan-Uganda border region. International Journal of Conflict and Violence 3(2): 188-203.

Lobell, B David; Marshall B Burke, Claudia Tebaldi, Michael D Mastrandrea, Walter P Falcon \& Rosamond Naylor (2008) Prioritising climate change adaptation needs for food security in 2030. Science 319(2): 607-610.

Maundu, Patrick; Dhynani J Berger, Charles Ole Saitabau, Joyce Nasieku, Moses Kipelian, Simon G Mathenge, Yasuyuki Morimoto \& Robert Höft (2001) Ethnobotany of the Loita Maasai: Towards Community Management of the Forest of the Lost Child: Experiences from the Loita Ethnobotany Project. People and Plants. Working Paper (8). Paris: UNESCO.

Mehlum, Halvor; Karl Moene \& Ragnar Torvik (2006) Institutions and the resource curse. Economic Journal 116 (1): $1-20$.

Mieth, Rika (2006) Defying the decline of pastoralism: Pokot perceptions of violence, disarmament and peacebuilding in the Kenya/Uganda Border Region. MA thesis. Amsterdam: Vrieje Universiteit.

Njogu, James (2004) Community-Based Conservation in an Entitlement Perspective: Wildlife and Forest Biodiversity Conservation in Taita, Kenya. Research Report (73). Leiden: African Studies Centre.

OECD (2008) Natural Resources and Pro-Poor Growth: The Economics and Politics. DAC Guidelines and Reference Series. Paris: Organization for Economic Cooperation and Development.

Ole Siloma, Morgan \& F Zaal (2005) Neo-African governance: Old and new institutions for resource conflict resolution. In: Mirjam AF Ros-Tonen \& Ton Dietz (eds) African Forests Between Nature and Livelihood Resource. Interdisciplinary Studies in Conservation and Forest Management. Lewiston: Mellen, 255-284.

Olsson, Lennart; Lars Eklundh \& Jonas Ardö (2005) A recent greening of the Sahel: Trends, patterns and potential causes. Journal of Arid Environments 63(3): 556-566.

Ostrom, Elinor (1990) Governing the Commons: The Evolution of Institutions for Collective Action. Cambridge: Cambridge University Press.

Ostrom, Elinor (2007) A diagnostic approach for going beyond panaceas. PNAS 104: 15181-15187.

Peluso, Nancy \& Michael Watts (eds) (2001) Violent Environments. Ithaca, NY: Cornell University Press.

Peristiany, John G (1939) The Social Institutions of the Kipsigis. London: Routledge.

Sachs, Jeffrey D \& Andrew M Warner (1997) Sources of slow growth in African economies. Journal of African Economies 6(3): 335-376.

Sachs, Jeffrey D \& Andrew M Warner (2001) The curse of natural resources. European Economic Review 45(4-6): 827-838.

Salih, MA Mohamed (1999) Environmental Politics and Liberation in Contemporary Africa. Dordrecht: Kluwer.

Schlee, Günther (2002) Imagined Differences: Hatred and the Construction of Identity. Münster: LIT.

Schlee, Günther (2008) How Enemies Are Made: Towards a Theory of Ethnic and Religious Conflicts. New York: Berghahn.

Sen, Amartya (1999) Development as Freedom. Oxford: Oxford University Press.

UNDP (2007) Human Development Report 2007/2008. Fighting Climate Change: Human Solidarity in a Divided World. United Nations Development Programme. New York: Palgrave Macmillan.

Witsenburg, Karen \& Wario R Adano (2007) The use and management of water sources in Kenya's drylands: Is there a link between scarcity and violent conflicts? In: Bill Derman, Rie Odgaard \& Espen Sjaastad (eds) Conflicts over Land and Water in Africa. Oxford: James Currey, 215-238.

Witsenburg, Karen \& Wario R Adano (2009) Of rains and raids: Violent livestock raiding in Northern Kenya. Civil Wars 11(4): 514-538. 
Young, Oran R (2011) Land use, environmental change and sustainable development: The role of institutional diagnostics. International Journal of the Commons 5(1): 66-85.

Zaal, Fred \& Morgan Ole Siloma (2006) Contextualising conflict: Introduced institutions and political networks combating pastoral poverty. Paper for World Bank conference, 27-28 June. Nairobi: Safari Park Hotel (http://www.saga. cornell.edu/saga/ilri0606/37zaal.pdf).

WARIO R ADANO, b. 1968, PhD in Behavioural Sciences (University of Amsterdam, 2004); Research Fellow at the Max Planck Institute, Halle/Saale (2007- ); Lecturer, School of Environmental Studies, Moi University, Kenya (2005- ). Main research interests: resource scarcity, conflicts, pastoral economy, pastoral sedentarization, social institutions, resource economics, poverty and climate change. Most recent book (with Karen Witsenburg): Pastoral Sedentarization, Natural Resource Management and Livelihood Diversification in Marsabit District, Northern Kenya (Mellen, 2008).
AJ (TON) DIETZ, b. 1951, PhD in Human Geography (University of Amsterdam, 1987); Professor, Leiden University (2010- ) and University of Amsterdam (1976- ); Director of the African Studies Centre Leiden (2010- ). Recent book: Silverlining Africa (Leiden University, 2011).

KAREN WITSENBURG, b. 1968, PhD in Human Geography (University of Amsterdam, 2004); Senior Policy Advisor, Both ENDS (2009- ); associate researcher, Max Planck Institute for Social Anthropology, Halle (2007- ). Main areas of interests: civil violence, natural resource management and human rights.

FRED ZAAL, b. 1960, PhD in Human Geography (University of Amsterdam, 1998), Senior Advisor, Royal Tropical Institute, Amsterdam (2009- ) and Assistant Professor, University of Amsterdam (1998-2009). Most recent book: Sustainable Land Management in the Tropics: Explaining the Miracle (ed., with Kees Burger, Ashgate, 2009). 